\title{
Correlation between detection rates of periodontopathic bacteria in atherosclerotic and subgingival plaques of Periodontitis Patients
}

\author{
Walid Altayeb,' Razan Khattab,' M Mazen Kabbani,, ${ }^{2}$ Fawza Monem, ${ }^{3}$ Mofeed Jokhadar ${ }^{4}$ \\ 'Department of Periodontology, Faculty of Dentistry, Damascus University, Syria \\ 2Department of Periodontology, University of Aleppo, Syria \\ ${ }^{3}$ Department of Microbiology, Alasad University Hospital, Damascus University, Syria \\ ${ }^{4}$ Department of Internal Medicine, Faculty of Medicine, Damascus University, Syria
}

Correspondence: Walid Altayeb, Department of Periodontology, Faculty of Dentistry, Damascus University, Syria, P.O.Box: I 3876, Al Waab, Doha, Qatar,Tel 0097460 I2199, Email dreltayeb@hotmail.com

Received: June 01, 2018 | Published: June 13,2018

Copyright@ 2018 Altayeb et al. This is an open access article distributed under the terms of the Creative Commons Attribution License, which permits unrestricted use, distribution, and reproduction in any medium, provided the original author and source are credited.

\begin{abstract}
Introduction: The investigations suggested that severe periodontal disease is associated with increased cardiovascular disease risk. Bacteremia due to periodontopathic bacteria may be an etiologic factor in atherosclerosis caused to cardiovascular disease. This study examined the association between atherosclerosis and periodontitis by detecting periodontopathic-associated bacterial DNA in atherosclerotic plaques.

Methods: 19patients scheduled to undergo carotid or coronary vessel surgery were enrolled in the study. Clinical measurements of periodontal indices were performed for each patient. Subgingival plaque samples were collected at least one week before the surgery. Atherosclerotic arterial plaque wall samples were harvested and examined for the presence of DNA corresponding to eleven different periodontopathic bacteria.

Results: The periodontopathic bacterial loads in atherosclerotic plaque samples was higher in the 10 periodontitis patients compared to the 9 healthy controls and the presence of periodontopathic bacteria in subgingival and atherosclerotic plaque samples positively correlated with periodontitis ( $\mathrm{p}<0.05$ ). The pathogens most frequently found in periodontitis were also found in atherosclerotic plaques especially P. gingivalis and T. forsythia in 8 and 7 samples respectively. The presence of bacteria in atherosclerotic plaques correlated with both periodontal disease severity and positive subgingival bacterial loads.

Conclusion: The presence of periodontal pathogens in atherosclerotic plaques of periodontitis patients established a link between periodontitis and cardiovascular disease. This bacterial presence in atherosclerotic plaques was only related to both severity of periodontal disease and positive subgingival bacterial loading together.
\end{abstract}

\section{Introduction}

Cardiovascular diseases (CVD) primarily are a result of atherosclerosis and are the number one cause of mortality worldwide. An estimated 17.5million people died from CVD in 2005, representing 30\% of all global deaths. ${ }^{1}$ Over $80 \%$ of CVD deaths take place in low- and middle-income countries. Globally, deaths from CVD are expected to reach 23.4 million by $2030 .^{2}$ The mechanisms resulting in pathology from both periodontitis and CVD are similar i.e., both diseases have complex causation that includes genetic and gender predispositions, age, diabetes, smoking, social status, and stress. ${ }^{3-8}$ Several epidemiologic studies have described conflicting links between periodontitis and cardiovascular disease. ${ }^{9-15}$

Chronic systemic inflammatory diseases, including infections with Chlamydia pneumoniae, Helicobacter pylori and cytomegalovirus have been hypothesized to contribute to the systemic development of arthrosclerosis. ${ }^{16-19}$ Periodontitis is a chronic, slow-progressing, asymptomatic inflammatory disease resulting from Gram-negative, anaerobic bacterial colonization of teeth at or below the gingival margin that can affect supporting tissues..$^{20}$ Recent evidence suggests that periodontopathogenic bacteria can also penetrate gin $\neg$ gival tissues, enter the circulation and contribute to atherosclerosis progression. ${ }^{21}$ The oral cavity of individuals with periodontitis represents a potentially large reservoir of Gram-negative pathogenic organisms. Perturbations to the oral cavity resulting from e.g., tooth brushing or mastication facilitate invasion of vascular tissues by bacteria. ${ }^{22}$ In more severe cases, bacteremia can result following tooth extraction, endodontic treatments, scaling or after the probing of periodontal pockets. ${ }^{23-26}$

Experimental animal studies demonstrated that oral infections with Porphyromonas gingivalis accelerated and enhanced atheroma formation. ${ }^{27}$ Another study showed that $P$. gingivalis bacteremia promoted coronary and aortic atherogenesis in pigs with or without significant hypercholesterolemia. ${ }^{28}$ Gibson et al. ${ }^{29}$ concluded that only fully-invasive $P$. gingivalis could accelerate plaque formation. A number of publications have demonstrated the presence of putative periodontal pathogens associated with atherosclerotic plaques. Haraszthy et $\mathrm{al}^{30}$ examined 50 carotid endarterectomy samples, ${ }^{22}$
Submit your Article | www. ologypress.com/submit-article OP, Ology $f$ in $y$ int
Citation: Altayeb W, Khattab R, Kabbani MM, et al. Correlation between detection rates of periodontopathic bacteria in atherosclerotic and subgingival plaques of Periodontitis Patients. J Dent Maxillofacial Res. (20I8); I (I): I824. DOI: $10.3088 \mathrm{I} / \mathrm{jds}$ somr.00006 
were positive for various bacteria, including Tannerella forsythia $(\mathrm{Tf})(30 \%), P$. gingivalis $(\mathrm{Pg})(26 \%)$, Prevotella intermedia (Pi) (14\%) and Aggregatibacter actinomycetemcomitans (Aa) (18\%). Taylor-Robinson et al. ${ }^{31}$ detected A. actinomycetemcomitans and/ or $P$. intermedia in $31 \%$ of arterial specimens and Stelzel et al. ${ }^{32}$ showed that $88.5 \%$ of aortic samples harvested during open heart surgery had DNA specific for bacteria associated with periodontal diseases. The aim of this study was to identify the presence of eleven periodontopathic bacteria (by DNA identification) in both subgingival and atherosclerotic plaques obtained from patients with chronic periodontitis disease hospitalized for carotid and coronary vessel endarterectomy and healthy controls.

\section{Materials and methods}

\section{Patients}

This study was a joint collaboration between the Department of Periodontics, Faculty of Dentistry (Damascus University) and the Department of Cardiology and Vascular Surgery (Alasad University Hospital) between May, 2004 and November, 2007. 19 Patients fulfilled the clinical entry criteria for the inclusion in this study i.e., dentate individuals ( $>12$ teeth) hospitalized for carotid and/or coronary vessel endarterectomy were examined by a single, experienced examiner. According to their periodontal condition they were divided into to controls (free of periodontal disease) or periodontitis patients.

Exclusion criteria included periodontal treatment or antibiotic treatment in the preceding 3 months or the use of antiseptic mouthwash three days prior to sample collection. Patient medical and dental histories were obtained via interview. The study was approved by the Ethics Committee of the Faculty of Dentistry and in $\neg$ formed consent was obtained from each subject.

\section{Clinical data collection}

Enrolled subjects received a periodontal examination at the dental facilities of Damascus University. Efforts were made to perform these examinations at least one week before surgery. Probing and sample collection of subgingival plaques 1week prior to collecting heart tissue samples likely did not affect the arterial plaque detection rates. ${ }^{33}$ The parameters recorded were as follows: probing pocket depth (PPD), clinical attachment loss $>5 \mathrm{~mm}(\mathrm{CAL}>5 \mathrm{~mm})$, bleeding on probing (BOP), number of teeth (NT) and probing pocket depth $>5 \mathrm{~mm}$ (PPD $>5 \mathrm{~mm}$ ). The periodontitis group consisted of ten subjects (6males and 4 females; mean age 51 years) with $>30 \%$ of their periodontal pockets having a probing depth of $>5 \mathrm{~mm}$ ( 5 pockets/patient were sampled). The control group consisted of nine subjects (6males and 3 females; average age 55.8years) who did not present with periodontal pocket depth of $>5 \mathrm{~mm}$.

\section{Subgingival plaque sample collection}

Subgingival plaque samples were collected using sterile paper points for every subject from five different sites (without suppuration) having the deepest periodontal probing depth. The samples were placed in individually labeled tubes and immediately frozen at $-20^{\circ} \mathrm{C}$. Total genomic DNA was isolated using a DNA isolation kit and used as a template for multiplex PCR using biotinylated primers (Roche Diagnostics GmbH, Mannheim, Germany). Subgingival bacteriological assays (DNA isolation, amplification and hybridization) were performed at the Hain Lifescience laboratories in Germany with the use of DNA strip technology based on the PCR-DNA probe method (MicroDent ${ }^{\circledR}$ and microDent ${ }^{\circledR}$ plus, Hain Lifescience $\mathrm{GmbH}$,
Nehren, Germany). The hybridization procedure included chemical denaturation of amplified products by hybridization to biotin-labeled amplicons to membrane-bound probes, stringent washing, addition of streptavidin alkaline phosphatase (AP) conjugate and substrate. Known standards of $10^{4}$ and $10^{7}$ for each bacteria examined were used for semi-quantitative quantification of individual species.

\section{Atheromatous plaque sample collection}

Atherosclerotic plaque samples were harvested during carotid and coronary endarterectomy and assayed for the presence and concentration of DNA specific to eleven periodontopathogenic bacteria. DNA was extracted from atherosclerotic plaque samples immediately using a DNA isolation kit (Puregene kit, Gentra Systems, Minneapolis, MN). Briefly, a section of the arterial wall (including the atherosclerotic plaque) was removed and the samples (approximately $100 \mathrm{mg}$ ) were dissociated with a spatula plus $150 \mu \mathrm{l}$ of Cell Lysis Solution (Puregene kit). Samples were then homogenized with a tube pestle and lysates were incubated at $65^{\circ} \mathrm{C}$ for $15 \mathrm{~min}$ followed by the addition of $0.75 \mu 1$ Proteinase K Solution and a subsequent incubation at $55^{\circ} \mathrm{C}$ for $3 \mathrm{~h}$ until tissue particulates were dissolved. Further incubations were performed for $30 \mathrm{~min}$ after the addition of RNase. After addition of protein precipitation solution (Puregene kit), lysates were centrifuged for $3 \mathrm{~min}$ at $16,000 \mathrm{xg}$. DNA was concentrated following the addition of $150 \mu 1$ of $100 \%$ isopropanol and DNA carrier (Gentra Glycogen Solution, $0.5 \mu 1$ glycogen $20 \mathrm{mg} / \mathrm{ml}$ ) was added to the super $\neg$ natants and subsequently centrifuged as above. The DNA pellets were obtained and stored at $-20^{\circ} \mathrm{C}$. The next two steps (PCR and hybridization) were carried out by the Hain Lifescience laboratories using the procedure described above for subgingival samples.

These tests identified eleven periodontopathogenic bacterial species i.e., A. actinomycetemcomitans, $P$. gingivalis, T. forsythia, Treponema denticola, P. intermedia, Campylobacter rectus, Fusobacterium nucleatem, Eikenella corrodens, Eubacterium nodatum, Peptostreptococcus micros, Capnocytophaga spp.

\section{Statistical analysis}

All bacterial specimens were coded so that measurements were carried out blindly. In-dependent Student- $t$ tests (assuming non-equal variances) were used to assess statistical differences between groups. The results from both subgingival and atherosclerotic samples were evaluated by the Mann-Whitney $U$ test for non-parametric data. A Spearman's correlation coefficient was calculated to analyze the relationship between periodontitis severity and bacterial loads in the periodontitis group. All data were analyzed using the Statistical Package for Social Sciences (SPSS, Chicago, IL) version 13.0 statistical software.

\section{Results}

Descriptive data and statistical analysis results of differences between select variables between the periodontitis and control groups are presented in Table 1. Age, gender, BMI and the number of remaining teeth did not differ between two groups. In addition, no biochemical parameter differences between groups were observed i.e., C-reactive protein (CRP), white blood cell (WBC) counts, cholesterol (CHOL), triglycerides (TG), high-density lipoprotein (HDL) or low-density lipoprotein (LDL) levels. However, differences in periodontal indices i.e., bleeding on probing (BOP), plaque index (PI), clinical attachment loss (CAL) and probing depths (PD) were significantly greater among periodontitis patients compared to controls $(\mathrm{P}<0.001$, Student's $t$-student test).
Submit your Article | www.ologypress.com/submit-article PP ${ }_{\text {Press }}^{\text {Ology } f \text { in } y \text { ritio }}$
Citation: Altayeb W, Khattab R, Kabbani MM, et al. Correlation between detection rates of periodontopathic bacteria in atherosclerotic and subgingival plaques of Periodontitis Patients. J Dent Maxillofacial Res. (20I8);I(I): I8-24. DOI: $10.3088 \mathrm{I} / \mathrm{jds}$ somr.00006 
Table I Descriptive statistics from subjects with or without periodontitis

\begin{tabular}{llll}
\hline Variable & $\begin{array}{l}\text { Group with periodontitis }(\mathbf{N}=\mathbf{l}) \\
\text { Mean } \pm \text { SD }\end{array}$ & $\begin{array}{l}\text { Group without periodontitis (N=9) } \\
\text { Mean } \pm \text { SD }\end{array}$ & $\begin{array}{l}\text { P value (Student's } \\
\mathbf{t} \text { test) }\end{array}$ \\
\hline Age & $51 \pm 7.4$ & $55.8 \pm 5.8$ & 0.06 \\
Gender (Male) & $6(60 \%)$ & $6(66.7 \%)$ & \\
Smoking habit Never & $4(40 \%)$ & $2(22.2 \%)$ & $5(55.5 \%)$ \\
Quit & $3(30 \%)$ & $2(22.2 \%)$ & 0.143 \\
Current & $3(30 \%)$ & $25.28 \pm 1.59$ & 0.544 \\
BMI, kg/m2 & $24.09 \pm 1.76$ & $22.22 \pm 3.63$ & $0.000^{*}$ \\
N teeth & $21.10 \pm 4.20$ & $0.69 \pm 0.52$ & $0.00 I^{*}$ \\
Plaque Index & $2.15 \pm 0.26$ & $20 \pm 7.42$ & $0.000^{*}$ \\
Bleeding Index $(\%)$ & $43.20 \pm 15.82$ & $1.96 \pm 0.30$ & $0.000^{*}$ \\
Probing Pocket Depth $(\mathrm{mm})$ & $4.69 \pm 0.55$ & 0 & $0.000^{*}$ \\
PPD>5.0 mm & $45.60 \pm 12.36$ & $10.56 \pm 7.63$ & 0.372 \\
CAL>5.0 mm & $57.30 \pm 15.09$ & $6.83 \pm 2.19$ & 0.865 \\
WBCs $(\times \mid 09 / \mu l)$ & $7.30 \pm 3.80$ & $6.18 \pm 1.84$ & 0.45 \\
CRP & $7.57 \pm 2.91$ & $247.90 \pm 96.05$ & 0.792 \\
Triglycerides & $260.25 \pm 100.47$ & $232.98 \pm 49.24$ & 0.257 \\
Cholesterol & $235.06 \pm 45.19$ & $42.13 \pm 7.81$ & 0.972 \\
HDL & $40.39 \pm 7.27$ & $136.11 \pm 34.14$ & \\
LDL & $135.91 \pm 34.55$ & & \\
\hline
\end{tabular}

$* p<0.05$

The amount of periodontopathic bacterial DNA in both subgingival and atherosclerotic plaque samples was classified for statistical purpose into 3 ordinal categories: bacterial loads under cut-off $\left(<10^{4}\right.$ pathogens), bacterial loads at cut-off $\left(10^{4}-10^{5}\right)$ and bacterial

loads over cut-off $\left(>10^{6}\right)$. The bacterial load distribution for each pathogen identified from respective samples from the periodontitis and control groups are described in (Tables 2) (Table 3).

Table 2 Detection rates of periodontopathic bacterial DNA in atherosclerotic and subgingival dental plaques from patients without periodontitis

\begin{tabular}{|c|c|c|c|c|c|}
\hline \multirow[t]{3}{*}{ Pathogens* } & \multirow{3}{*}{$\begin{array}{l}\text { Sample sites (subgingival/ } \\
\text { atherosclerotic plaque) }\end{array}$} & \multicolumn{3}{|c|}{ Bacterial load (number of patients) } & \multirow{3}{*}{$\begin{array}{l}\text { Mann-Whitney U } \\
\text { Test p-values }\end{array}$} \\
\hline & & $\begin{array}{l}\text { (None detected) } \\
\text { Below cut-off }\end{array}$ & Detected & $\begin{array}{l}\text { High } \\
\text { detected }\end{array}$ & \\
\hline & & $<10^{4}$ & $10^{4}-10^{5}$ & $>10^{6}$ & \\
\hline \multirow[t]{2}{*}{$A a$} & subgingival & 9 & 0 & 0 & 0.317 \\
\hline & Atherosclerotic & I & 0 & 0 & \\
\hline \multirow[t]{2}{*}{$\mathrm{Pg}$} & subgingival & 8 & I & 0 & 0.248 \\
\hline & Atherosclerotic & 6 & 3 & 0 & \\
\hline \multirow[t]{2}{*}{$\mathrm{Pi}$} & subgingival & 9 & 0 & 0 & I \\
\hline & Atherosclerotic & 9 & 0 & 0 & \\
\hline \multirow[t]{2}{*}{ Tf } & subgingival & 7 & 2 & 0 & 0.145 \\
\hline & Atherosclerotic & 9 & 0 & 0 & \\
\hline \multirow[t]{2}{*}{$T d$} & subgingival & 8 & I & 0 & 0.936 \\
\hline & Atherosclerotic & 8 & I & 0 & \\
\hline \multirow[t]{2}{*}{ Pm } & subgingival & 9 & 0 & 0 & I \\
\hline & Atherosclerotic & 9 & 0 & 0 & \\
\hline
\end{tabular}


(Table 2 continue..)

\begin{tabular}{|c|c|c|c|c|c|}
\hline \multirow[t]{2}{*}{ Fn } & subgingival & 2 & 3 & 4 & \multirow[t]{2}{*}{$0.023 * *$} \\
\hline & Atherosclerotic & 5 & 4 & 0 & \\
\hline \multirow[t]{2}{*}{$\mathrm{Cr}$} & subgingival & 7 & 2 & 0 & \multirow[t]{2}{*}{0.146} \\
\hline & Atherosclerotic & 9 & 0 & 0 & \\
\hline \multirow[t]{2}{*}{ En } & subgingival & 9 & 0 & 0 & \multirow[t]{2}{*}{ I } \\
\hline & Atherosclerotic & 9 & 0 & 0 & \\
\hline \multirow[t]{2}{*}{ Ec } & subgingival & 3 & 3 & 3 & \multirow[t]{2}{*}{$0.012^{* *}$} \\
\hline & Atherosclerotic & 8 & I & 0 & \\
\hline \multirow[t]{2}{*}{ Cs } & subgingival & 4 & 2 & 3 & \multirow[t]{2}{*}{0.095} \\
\hline & Atherosclerotic & 7 & 2 & 0 & \\
\hline
\end{tabular}

*Aa, A. actinomycetemcomitans; Pg, P. gingivalis;Tf,T. forsythia;Td, T. denticola; Pi, P. intermedia; Cr, C. rectus; Fn, F. nucleatem; Ec, E. corrodens; En, E. nodatum; Pm, P. micros; Cs, Capnocytophaga spp

$* * p<0.05$.

Table 3 Detection rates of periodontopathic bacterial DNA in atherosclerotic and subgingival dental plaques from periodontitis patients.

\begin{tabular}{|c|c|c|c|c|c|}
\hline \multirow[t]{2}{*}{ Pathogens* } & \multirow[t]{2}{*}{$\begin{array}{l}\text { Sample sites (subgingival/ } \\
\text { atherosclerotic plaque) }\end{array}$} & \multicolumn{3}{|c|}{$\begin{array}{l}\text { Bacterial load (number of } \\
\text { patients) }\end{array}$} & \multirow[t]{2}{*}{$\begin{array}{l}\text { Mann-Whitney U } \\
\text { Test p-values }\end{array}$} \\
\hline & & $\begin{array}{l}\text { (None detected } \\
\text { Below cut-off) }<10^{4}\end{array}$ & $\begin{array}{l}\text { Detected } \\
10^{4}-10^{5}\end{array}$ & $\begin{array}{l}\text { High } \\
\text { detected } \\
>10^{6}\end{array}$ & \\
\hline \multirow[t]{2}{*}{$A a$} & subgingival & 9 & 0 & 0 & 0.317 \\
\hline & Atherosclerotic & 1 & 0 & 0 & \\
\hline \multirow[t]{2}{*}{$\mathrm{Pg}$} & subgingival & 8 & I & 0 & 0.248 \\
\hline & Atherosclerotic & 6 & 3 & 0 & \\
\hline \multirow[t]{2}{*}{$P i$} & subgingival & 9 & 0 & 0 & I \\
\hline & Atherosclerotic & 9 & 0 & 0 & \\
\hline \multirow[t]{2}{*}{ Tf } & subgingival & 7 & 2 & 0 & 0.145 \\
\hline & Atherosclerotic & 9 & 0 & 0 & \\
\hline \multirow[t]{2}{*}{$T d$} & subgingival & 8 & I & 0 & 0.936 \\
\hline & Atherosclerotic & 8 & I & 0 & \\
\hline \multirow[t]{2}{*}{$P m$} & subgingival & 9 & 0 & 0 & I \\
\hline & Atherosclerotic & 9 & 0 & 0 & \\
\hline \multirow[t]{2}{*}{ Fn } & subgingival & 2 & 3 & 4 & $0.023 * *$ \\
\hline & Atherosclerotic & 5 & 4 & 0 & \\
\hline \multirow[t]{2}{*}{$\mathrm{Cr}$} & subgingival & 7 & 2 & 0 & 0.146 \\
\hline & Atherosclerotic & 9 & 0 & 0 & \\
\hline \multirow[t]{2}{*}{ En } & subgingival & 9 & 0 & 0 & I \\
\hline & Atherosclerotic & 9 & 0 & 0 & \\
\hline \multirow[t]{2}{*}{ Ec } & subgingival & 3 & 3 & 3 & $0.012^{* *}$ \\
\hline & Atherosclerotic & 8 & I & 0 & \\
\hline \multirow[t]{2}{*}{ Cs } & subgingival & 4 & 2 & 3 & 0.095 \\
\hline & Atherosclerotic & 7 & 2 & 0 & \\
\hline
\end{tabular}

*Aa, A. actinomycetemcomitans; Pg, P. gingivalis;Tf,T. forsythia;Td, T. denticola; Pi, P. intermedia; Cr, C. rectus; Fn, F. nucleatem; Ec, E. corrodens; En, E. nodatum; Pm, P. micros; Cs, Capnocytophaga sppp

$* * p<0.05$ 
The most common pathogen identified in atherosclerotic plaques from periodontitis patients were $P$. gingivalis, E. corrodens, T. forsythia, F. nucleatem and A. actinomycetemcomitans, respectively. The DNA most commonly isolsated from control samples was from either F. nulceateum, P. gingivalis or Capnocytophaga spp. Statistical analysis demonstrated that the detection of all studied organisms in atherosclerotic plaque samples significantly correlated with colonization by these organisms in subgingival sites in both groups $(\mathrm{P}<0.05$; Mann-Whitney UTest). F. nucleateum and E. corrodens were present at higher concentrations in subgingival verses atherosclerotic samples in the control group (Table 2) and P. micros and E. corrodens were present at higher concentrations in atherosclerotic plaques compared to the concentrations obtained in the subgingival plaques of periodontal patients (Table 3).

The frequency of the selected bacteria in subgingival samples of both periodontitis and control groups is described in Figure 1. For

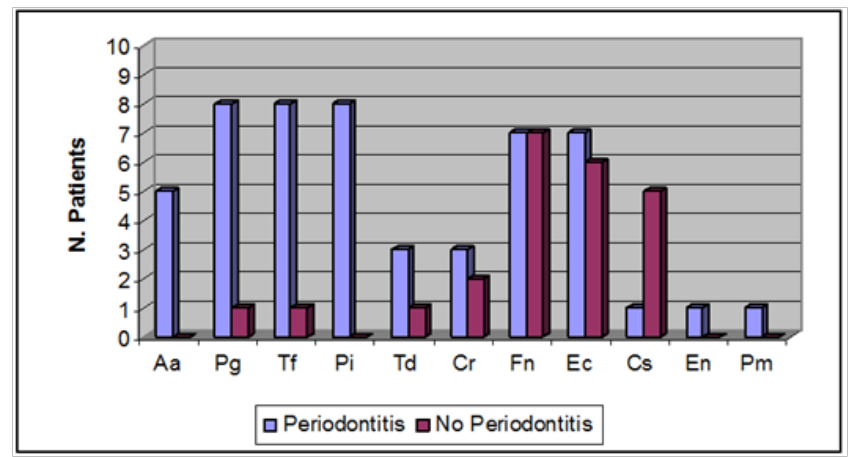

Figure I Frequency of periodontopathic bacterial DNA in subgingival plaques between patients with and without periodontitis.

Aa, A. actinomycetemcomitans; Pg, P. gingivalis; Tf, T. forsythia; Td, T. denticola; Pi, P. intermedia; Cr, C. rectus; Fn, F. nucleatem; Ec, E. corrodens; En, E. nodatum; Pm, P. micros; Cs, Capnocytophaga spp

\section{Discussion}

This study confirmed recent reports that suggested that total bacterial loads in subgingival and atherosclerotic plaques were higher in periodontitis patients compared to healthy individuals. The presence of bacteria in atherosclerotic plaques correlated with both periodontal disease severity (i.e., high prevalence of periodontal pockets) and positive subgingival bacterial loads. No correlation was observed in healthy controls. These data suggested that bacterial colonization associated with severe periodontitis was also associated with arthrosclerosis.

The data presented in this report demonstrated a positive linear relationship between periodontitis severity (defined by increased probe depths) and increased concentrations of $P$. gingivalis, $T$. forsythia, $P$. micros and E. corrodens in atherosclerotic plaques. Increased probing depths served as an indicator of an increasing subgingival infection surface area. Subgingival bacterial biofilms would be capable of sustaining a significant bacterial load by providing a constant source of lipopolysaccharides (LPS) and increasing the risk of Gram-negative bloodstream dissemination. ${ }^{34}$ The epithelial lining of the periodontal pocket, which frequently becomes thin and ulcerated during the course of periodontitis, may provide subgingival plaque bacteria with
9 of 11 species examined, higher bacterial loads were found in the periodontitis group with the exception of Capnocytophaga spp. which was present at significantly higher frequencies in subgingival samples of the control group $(\mathrm{P}<0.05$, Mann-Whitney $U$ Test $)$.

Figure 2 represents the frequencies of the selected bacteria in atherosclerotic plaque samples of individuals with or without periodontitis. The detection frequencies for all 11-species examined was higher in the periodontitis group compared to the control group and the frequencies for $P$. gingivalis, T. forsythia, P. micros, $C$. rectus, E. corrodens and Capnocytophaga spp. were significantly higher $(\mathrm{P}<0.05$, Mann-Whitney $U$ Test $)$. There was a significant, positive linear correlation between probing depth and subgingival A. actinomycetemcomitans, $P$. gingivalis, $P$. intermedia, and T. forsythia loads and a positive linear correlation between probing depth and the presence of $P$. gingivalis, $T$. forsythia, $P$. micros, $E$. corrodens in atherosclerotic plaques.

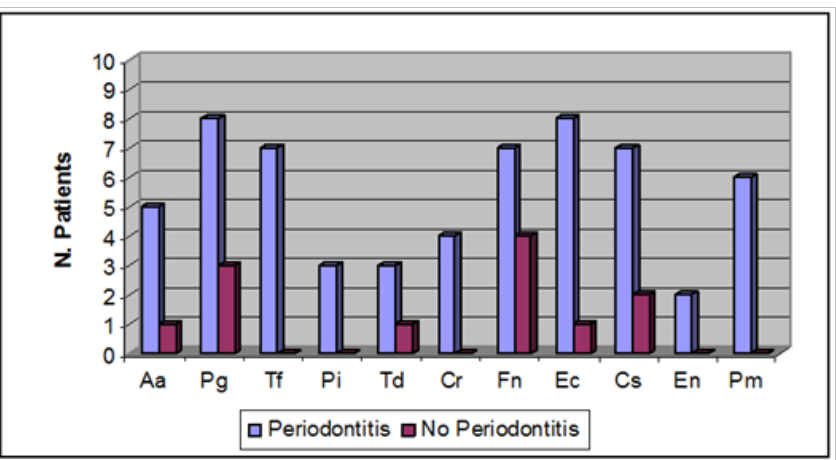

Figure 2 Frequency of periodontopathic bacterial DNA in atherosclerotic plaques between patients with and without periodontitis.

Aa, A. actinomycetemcomitans; Pg, P. gingivalis; Tf, T. forsythia; Td, T. denticola; Pi, P. intermedia; Cr, C. rectus; Fn, F. nucleatem; Ec, E. corrodens; En, E. nodatum; Pm, P. micros; Cs, Capnocytophaga spp

an entry point thereby facilitating access to the underlying tissues and to the vasculature. ${ }^{35}$ It has been demonstrated that subgingival bacteria, such as $P$. gingivalis, E. corrodens, $P$. intermedia and $A$. actinomycetemcomitans, are able to invade epithelium, endothelium, and vascular smooth muscle cells. ${ }^{36}$ Dorn et al. ${ }^{37}$ found that certain strains of $P$. gingivalis and $P$. intermedia were also able to invade coronary artery cells.

In the present study, detection rates for most periodontal pathogens associated with atherosclerotic plaques correlated with subgingival plaque detection rates from periodontitis patients. For example, we detected $P$. gingivalis in both atherosclerotic and subgingival plaque samples from 8 of 10 periodontitis patients. This outcome was not consistent with a study by Zaremba et al. ${ }^{38}$ who did not observe a correlation between the amount of bacteria in subgingival pockets and the numbers found in coronary vessels even though $P$. gingivalis, T. forsythia and T. denticola were found in samples collected from cardiac vessels. Zaremba et al. observed that the formation of periodontal pockets $>4 \mathrm{~mm}$ was higher in patients with periodontal pathogens isolated from atherosclerotic plaques compared to patients without atherosclerotic pathogens and observed that the bleeding index had a significant impact on blood stream dissemination.
Submit your Article | www.ologypress.com/submit-article OP O Press $f$ in $y$ wirit
Citation: Altayeb W, Khattab R, Kabbani MM, et al. Correlation between detection rates of periodontopathic bacteria in atherosclerotic and subgingival plaques of Periodontitis Patients. J Dent Maxillofacial Res. (20I8); I(I):I8-24. DOI: $10.3088 \mathrm{I} / \mathrm{jdsomr.00006}$ 
Individuals may be colonized persistently by periodontal pathogens at or below the gingival margin and not show evidence of ongoing or previous periodontal degeneration. This observation may help explain why some pathogens (i.e., Capnocytophaga spp., F. nucleatem, E. corrodens and $C$. rectus) could be detected in subgingival samples of individuals without periodontitis. This report demonstrated that the presence of DNA from some periodontopathic bacteria i.e., $F$. nucleatem and E. corrodens in atherosclerotic plaques of periodontally healthy patients may be unrelated to atherosclerotic plaque formation.

$P$. gingivalis was the bacteria most frequently associated with atherosclerotic plaques and the predominant species identified among anaerobic bacteria isolated from dental procedure-associated bacteremia. ${ }^{39}$ Ishihara et al. ${ }^{40}$ demonstrated that the presence of only $P$. gingivalis and $C$. rectus in the oral cavity correlated with their presence in coronary artery samples. This association was not observed for other microorganisms such as T. denticola even though T. denticola was detected at high numbers in atherosclerotic lesions. Since the micro flora of periodontal lesions was not consistent betweens lesions, multiple lesions will need to be evaluated in order to clarify issues relating to what other strains may also be associated with atherosclerotic plaque formation e.g., Ishihara et al. only sampled two periodontal lesion sites/patient compared to 5 lesions/patient examined in the present study.

Pucar et al. ${ }^{41}$ found that $60 \%$ of the atherosclerotic coronary arteries contained DNA from bacteria potentially associated with periodontal disease compared to $0 \%$ in clinically healthy internal mammary arteries (considered to be protected from atherosclerosis). In contrast, Elkaim et al..$^{42}$ investigated the presence of 20 periodontal bacterial species in atherosclerotic samples and healthy blood vessels. The presence of periodontal pathogens in atherosclerotic plaques and in apparently healthy vessels was similar and appeared to reflect a higher level of bacteremia rather than endothelial cell infection.

Detection of periodontopathic bacteria in atherosclerotic plaques in this study correlated with subgingival bacterial loads. These observations, taken together with the large amount of alreadypub $\neg$ lished epidemiological, microbiological, and clinical data further demonstrated the link between periodontitis and cardiovascular disease. Additional studies will be required to determine whether periodontal pathogens represent a novel risk factor for atherogenesis.

\section{Conclusion}

Bacterial presence in atherosclerotic plaques was only related to both severity of periodontal disease and positive subgingival bacterial loading together. Bacteremia due to periodontopathic bacteria may be an etiologic factor in atherosclerosis caused to cardiovascular disease.

\section{Acknowledgements}

The authors would like to thank the Faculty of Dentistry, Damascus University and Prof. Marwan Shamiah, Director of Vessels and Heart Surgery Center for his invaluable help with atherosclerotic plaque sample collection. We would also like to thank Dr. Wafaa Habal for her help with DNA preservation and isolation from atherosclerotic plaque samples.

\section{Conflict of interest and sources of funding statement}

This study was supported by Syrian Ministry of Higher Education, Damascus University and Alasad University Hospital. The authors declare that there are no conflicts of interest relating to this work.

\section{References}

1. World Health Organization, Fact Sheet 317. Cardiovascular diseases. USA: WHO; 2007.

2. World Health Organization. Future trends in global mortality: major shifts in cause of death patterns. World health statistics. France: WHO; 2008.

3. Beck JD, Garcia RI, Heiss G, et al. Periodontal disease and cardiovascular disease. J Periodontol. 1996;67:1123-1137.

4. Kinane DF, Lowe GDO. How periodontal disease may contribute to cardiovascular disease. Periodontol. 2000; 23:121-126.

5. Ross R. Atherosclerosis is an inflammatory disease. Am Heart J. 1999;138(5 Pt 2):419-420.

6. Libby P, Ridker PM, Maseri A. Inflammation and atherosclerosis. Circulation. 2002;105:1135-1143.

7. Mehta JL, Saldeen TG, Rand K. Interactive role of infection, inflammation and traditional risk factors in atherosclerosis and coronary artery disease. J Am Coll Cardiol. 1998;31(6):1217-1225.

8. Braunwald E. Cardiovascular medicine at the turn of the millennium: triumphs, concerns, and opportunities. N Engl J Med. 1997;337:13601369.

9. Arbes SJ, Slade GD, Beck JD. Association between extent of periodontal attachment loss and self-reported history of heart attack: an analysis of NHANES III data. J Dent Res.1999;78(12):1777-1782.

10. Khader YS, Albashaireh ZS, Alomari MA. Periodontal diseases and the risk of coronary heart and cerebrovascular diseases: A meta-analysis. $J$ Periodontol. 2004;75(8):1046-1053.

11. Desvarieux M, Demmer RT, Rundek T, et al. Relationship between periodontal disease, tooth loss, and carotid artery plaque: the Oral Infections and Vascular Disease Epidemiology Study (INVEST). Stroke. 2003;34(9): 2120-2125.

12. Geismar K, StoltzeK, SigurdB, et al. Periodontal disease and coronary heart disease. J Periodontol. 2006;77(9):1547-1554.

13. Briggs JE, McKeown PP, Crawford VLS, et al. Angiographically confirmed coronary heart disease and periodontal disease in middle-aged males. J Periodontol. 2006;77(1):95-102.

14. Howell TH, Ridker PM, Ajani UA, et al. Cardiovascular disease in U.S. male physicians. J Am Coll Cardiol. 2001; 37: 445-450.

15. Hujoel PP, Drangsholt M, Spiekerman C, et al. Pre-existing cardiovascular disease and periodontitis: a follow-up study. J Dent Res. 2002;81(3):186191.

16. Chiu B, Viira E, Tucker W, et al. Chlamydia pneumoniae, cytomegalovirus, and herpes simplex virus in atherosclerosis of the carotid artery. Circulation. 1997;96:2144-2148.

17. Valtonen VV. Role of infections in atherosclerosis. Am Heart J. 1999;138(5 Pt 2):S431- 433.

18. Danesh J. Coronary heart disease, Helicobacter pylori, dental disease, chlamydia pneumoniae, and cytomegalovirus: meta-analyses of prospective studies. Am Heart J. 1999;138(5 Pt 2):434-437.

19. Jackson LA, Campbell LA, Kuo CC, et al. Isolation of chlamydia pneumoniae from a carotid endarterectomy specimen. $J$ Infect Dis. 1997;176(1): 292-295.

20. Socransky SS, Haffajee AD. Microbiology of periodontal disease. In: Lindhe J, et al. editors. Clinical Periodontology and Implant Dentistry. 4th ed. Oxford, UK. Blackwell Munksgaard; 2003. p. 106-112.
Submit your Article | www.ologypress.com/submit-article OP Ology $f$ in $y$ ress
Citation: Altayeb W, Khattab R, Kabbani MM, et al. Correlation between detection rates of periodontopathic bacteria in atherosclerotic and subgingival plaques of Periodontitis Patients. J Dent Maxillofacial Res. (20I8); I(I):I8-24. DOI: $10.3088 \mathrm{I} / \mathrm{jdsomr} .00006$ 
21. Genco R, Offenbacher S, Beck J. Periodontal disease and cardiovascular disease: epidemiology and possible mechanisms. J Am Dent Assoc. 2002;133 Suppl:14-22S.

22. Sabine OG, Monique N, Patrick DM, et al. Systemic release of endotoxins induced by gentle mastication: association with periodontitis severity. $J$ Periodontol. 2002;73(1):73-78.

23. Heimdahl A, Hall G, Hedberg M, et al. Detection and quantification by lysis-filtration of bacteremia after different oral surgical procedures. $J$ Clin Microbiol. 1990;28(10):2205-2209.

24. Kinane DF, Riggio MP, Walker KF, et al. Bacteraemia following periodontal procedures. J Clin Periodontol. 2005;32(7):708-713.

25. FornerL, LarsenT, Kilian M, et al. Incidence of bacteremia after chewing, tooth brushing and scaling in individuals with periodontal inflammation. $J$ Clin Periodontol. 2006;33(6):401-407.

26. Padilla EC, Lobos GO, Jure OG, et al. Isolation of periodontal bacteria from blood samples and atheromas in patients with atherosclerosis and periodontitis. Rev Med Chil. 2007;135(9):1118-1124.

27. Lalla E, Lamster IB, Hofmann MA, et al. Oral infection with a periodontal pathogen accelerates early atherosclerosis in apolipoprotein E-null mice. Arterioscler Thromb Vasc Biol. 2003; 23(8):1405-1411.

28. Brodala N, Merricks EP, Bellinger DA, et al. Porphyromonas gingivalis bacteremia induces coronary and aortic atherosclerosis in normocholesterolemic and hypercholesterolemic pigs. Arterioscler Thromb Vasc Biol. 2005;25(7):1446-1451.

29. Gibson FC, Hong $\mathrm{C}$, Chou $\mathrm{HH}$, et al. Innate immune recognition of invasive bacteria accelerates atherosclerosis in apolipoprotein E-deficient mice. Circulation. 2004;109(22):2801-2806.

30. Haraszthy VI, Zambon JJ, Trevisan M, et al. Identification of periodontal pathogens in atheromatous plaques. J Periodontol. 2000;71(10):1554 -1560 .

31. Taylor-Robinson D, Aduse-Opoku J, Sayed P, et al. Oro-dental bacteria in various atherosclerotic arteries. Eur J Clin Microbiol Infect Dis.
2002;21(10):755-757.

32. Stelzel M, Conrads G, Pankuweit S, et al. Detection of Porphyromonas gingivalis DNA in aortic tissue by PCR. J Periodontol. 2002;73(8):868870 .

33. Roberts GJ, Gardner P, Simmons NA. Optimum sampling time for detection of dental bacteraemia in children. Int J Cardiol. 1992;35(3):311315 .

34. Haffajee AD, Socransky SS. Microbial etiological agents of destructive periodontal diseases. Periodontol. 1994;5:78-111.

35. Williams RC, Paquette D. Periodontitis as a risk for systemic disease In: Lindhe J, et al. editors. Clinical Periodontology and Implant Dentistry. 4th ed. Oxford, UK: Blackwell Munksgaard; 2003: 366-386.

36. Kuramitsu HK, Kang IC, Qi M. Interactions of Porphyromonas gingivalis with host cells: implications for cardiovascular diseases. J Periodontol. 2003;74(1):85-89.

37. Dorn BR, Dunn WA, Progulske-Fox A. Invasion of human coronary artery cells by periodontal pathogens. Infect Immun. 1999;67(11):5792-5798.

38. Zaremba M, GórskaR, SuwalskiP, et al. Evaluation of the incidence of periodontitis-associated bacteria in the atherosclerotic plaque of coronary blood vessels. J Periodontol. 2007;78(2):322-327.

39. Messini M, Skourti I, Markopulos E, et al. Bacteremia after dental treatment in mentally handicapped people. J Clin Periodontol. 1999;26(7):469-473.

40. Ishihara K, Nabuchi A, Ito R, et al. Correlation between detection rates of periodontopathic bacterial DNA in carotid coronary stenotic artery plaque and in dental plaque samples. J Clin Microbiol. 2004;42(3):1313-1315.

41. Pucar A, Milasin J, Lekovic V, et al. Correlation between atherosclerosis and periodontal putative pathogenic bacterial infections in coronary and internal mammary arteries. J Periodontol. 2007;78(4):677-682.

42. Elkaim R, Dahan M, Kocgozlu L, et al. Prevalence of periodontal pathogens in subgingival lesions, atherosclerotic plaques and healthy blood vessels: a preliminary study. J Periodontal Res. 2008;43(2):224 231. 